\title{
Grassland management in protected areas - implementation of the EU biodiversity strategy in certain post-communist countries
}

\section{Ágnes Balázsi*}

Keywords: barriers to conservation, nature-people disconnection, knowledge gaps, policy, practice, traditional farming landscapes.

\section{Ključne besede: ovire v} naravovarstvu, nepovezanost narave in ljudi, pomanjkanje znanja, politika, praksa, tradicionalna kmetijska krajina.
Received: 3. 2. 2017

Revision received: 1.9 .2017

Accepted: 31. 10. 2017

\section{Co-ordinating Editor:}

Michał Żmihorski

\begin{abstract}
The post-communist countries of Central-Eastern Europe (CEE) when implementing agricultural and conservation policies, face other challenges than Western European countries: (1) specific institutional design for each, developed on the remnants of totalitarian system causing difficulties for transposing directives; (2) different integration of Natura 2000 network into national protected area governance resulting in slow elaboration of the management plans; (3) farming landscapes were better preserved than in Western Europe, but lacking the continuity of extensive farming so large areas of conservation; and (4) formal protection of sites, lacking in many cases financial support. This paper summarizes: the historical background of the last century that changed the farming landscapes of the CEE countries and the challenges in the management of protected areas in an unsteady socio-economic and political context. The results are focusing on the Czech Republic, Slovakia, Hungary and Romania. Two main conclusions are proposed. First, socialism and capitalism slowly abolished family farming, causing people to become disconnected from the landscape - a key element in conservation oriented grassland management. Second, the gaps of knowledge on different aspects of policy implementation sabotage the results of conservation initiatives.
\end{abstract}

\section{Izvleček}

Postkomunistične države iz srednje in vzhodne Evrope (CEE) se pri uvajanju kmetijskih in naravovarstvenih politik soočajo z drugačnimi izzivi kot zahodnoevropske države: (1) specifična ureditev inštitucij v vsaki državi, ki se je razvila na ostankih totalitarnega sistema in ki povzorča težave pri prenosu direktiv; (2) različna integracija omrežja Natura 2000 v upravljanje z zavarovanimi območji na nacionalni ravni, ki se odraža v slabi izdelavi načrtov upravljanja; (3) kmetijska krajina je bila bolje ohranjena kot v zahodni Evropi, vendar se je prenehalo kontinuirano ekstenzivno gospodariti, je pa zato moč ohraniti velika območja; in (4) določena območja so uradno zaščitena, a z nezadostnim financiranjem gopodarjenja. V članku povzemamo zgodovinsko ozadje v preteklem stoletju, ki je spremenilo kmetijsko krajino v državah CEE in izzive gospodarjenja z zavarovanimi območji v negotovih socio-ekonomskih in političnih razmerah. Rezultati temeljijo na kabinetnih raziskavah, osredotočenih na razmere na Češkem, Slovaškem, na Madžarskem in v Romuniji. Predlagamo dve glavni ugotovitvi. Prvič, socializem in kapitalizem sta počasi privedla do ukinitve družinskih kmetij in nepovezanosti ljudi s krajino, to pa je glavni element sonaravnega gospodarjenja s travišči. Drugič, pomanjkanje znanja o različnih vidikih izvajanja politike onemogočajo rezultate naravovarstvenih pobud.

\footnotetext{
* Sapientia Hungarian University of Transylvania, Department of Environmental Studies, Calea Turzii 4, 400193, Cluj-Napoca, Romania. E-mail: balazsi.agnes.sapientia@gmail.com
} 


\section{Introduction}

The new EU Biodiversity Strategy proposes to halt biodiversity loss and the degradation of ecosystem services by 2020. It is an ambitious proposal, built around six targets, each supported by a set of actions. The mid-term report in 2015 on the Biodiversity Strategy 2020 concluded that overall, no significant progress has been achieved since 2011 (European Commission 2015). Despite that, EU indicators for the conservation status of the habitats and species (SEBI 03, SEBI 05) show increasing tendency (Target 1), the most emergent actions will remain the efficient management of the Natura 2000 network and its financial support (Kati et al. 2014, Blicharska et al. 2016).

In this paper Target 1 and Target $3 \mathrm{~A}$ are specifically addressed because these have a direct influence on grassland management in protected areas. Target 1 is designed to achieve the appropriate implementation of the Habitats and Birds Directives and Target 3A designed to integrate biodiversity policy into agriculture (Common Agricultural Policies) and forestry.

Grassland management in protected areas is a very specific, but transdisciplinary process, where conflicting policy implementation must be harmonized (agriculture $v s$. nature conservation). When it comes to policy harmonization, the post-communist member states are in a special situation. First, farming landscapes and biodiversity have survived industrialization trends of the last century in better ecological shape than in developed countries. Consequently, conservation has to embrace social-ecological systems in their complexity, rather than just patches of habitats and number of species. Second, the success of transposing those conflicting EU directives depends on the institutional structure of the authorities and their cooperation. The centralized governmental system reduces the ability of many authorities to implement strategies, programs which respond to regional, or local challenges (Henle et al. 2008, Stoate et al. 2009).

The main aim of this paper is to summarize the constraints and identify challenges for the future of grassland conservation in protected areas in four post-communist countries of Central-Eastern Europe (CEE): the Czech Republic, Slovakia, Hungary and Romania.

\section{Methods}

This paper includes a desk study focused on the Czech Republic, Slovakia, Hungary and Romania and field visits in six protected areas in the Czech Republic, Slovakia and Hungary.

The desk study reviewed the relevant scientific and grey literature. The selection of papers was conducted in Google Scholar, using the name of the country and different keywords: protected areas, Natura 2000, land use-changes, post-socialist/communist, agricultural landscape. The review of grey literature included documents that transpose EU directives on biodiversity conservation and agriculture into national legislation in each country; EU reports on the Biodiversity Strategy, national rural development plans and strategies, and websites of governmental and non-governmental institutions, relevant for nature conservation and agriculture.

Participant observations and five semi-structured interviews took place with farmers and employees of protected areas, in 2016. The protected areas visited were the Krkonoše Mountains National Park and the White Carpathians Protected Landscape Area - Czech Republic; the Low Tatras National Park and the Great Fatra National Park - Slovakia; the Hortobágy National Park and the Bükk National Park - Hungary. I spent one week in each, being involved in every day's work of the employees (rangers, botanists, ornithologist, managers, and administrative persons). The observations and interviews concentrated on five topics: (1) public administration structure, (2) management plans of the protected areas and conservation measures for grassland habitats, (3) monitoring, (4) reward systems and (5) collaboration with the stakeholders. Interviewees were selected from individuals who has interest in grassland management (actively involved -2 farmers; administratively involved -3 protected area employees, just in cases where participant observation and discussions could not cover the topic of the study).

\section{Results and discussions}

\section{Overview on the last century - changes in agriculture and loss of semi-natural grassland biodiversity}

During the last century dramatic political changes have taken place in the countries of CEE including several land reforms, two world wars, establishment and collapse of the communist regime and the accession to the market economy of Europe (Bogaerts et al. 2002). All of these changes have generated shifts in the boundaries of different countries and large transmigration of people (Germans from Czechoslovakia and Sachsen from Romania), resulting in the disconnection of cultural components from landscapes (Van Dijk 2007). It is considered that the management and conservation of grasslands can be better understood if the socio-economic changes of the last century are also considered (Hartel et al. 2014). 


\section{During socialism}

The land reforms and land management after 1945 have had important consequences for nature conservation and protected area management. The abolition of smallscale farm systems due to collectivization in 1945-1962 has generated a series of changes in the structure and function of rural landscapes in Slovakia (Lieskovský et al. 2015), Czech Republic (Bič́k et al. 2001) Hungary (Burger 2006) and Romania (Fischer et al. 2012). The disconnection of whole generations from their land, changes in traditional practices (e.g. paradigm changes towards production oriented agriculture) have been the most significant losses of the 20th century from the nature conservation point of view (Isselstein et al. 2005, Varga et al. 2016).

The wave of designation of protected areas of national importance began in the CEE counties in the late 1960s, early 1970 s and focusing on the most valuable areas of the countries. They were established during the communist era with a top-down approach and minimal public discussion (Švajda \& Fenichel 2011). Large areas were formally designated but with inadequate management resources for their administration (Iojă et al. 2010). Other barriers were the continuously changing social contexts, combined with product oriented economic and agricultural paradigms of the last century. Moreover, nature conservation paradigms considered protected areas as some untouchable areas by humans. This changed the traditional grassland management in many areas, without taking into account their values from conservational point of view (Bičíket al. 2001, Lemaire et al. 2005, Mikulcak et al. 2015, Levers et al. 2016).

\section{After socialism}

The period after the soviet era (i.e. after 1989) could be described by the trend of migration from rural to urban areas in the search of higher living standards, compounded disconnection of people from their land in the countryside. The most important change, which had repercussions on grassland management was the fluctuations in livestock numbers and changes in extensive grazing systems (Varga et al. 2016). After the end of communist cooperatives, privatization happened quickly for the most productive areas, while unproductive areas suffered from the disinterest of investments, bad infrastructure and restricted production (Van Dijk 2007, Gorlach et al. 2008). The need to develop market networks in the EU for the new farming structure (private, medium to big) urgently overwhelmed the newly formed countries (Bezák \& Mitchley 2014).
The management and governance of protected areas became significantly more complex after the property rights restitution and landownership changes (Oszlányi et al. 2004, Knorn et al. 2012, Kluvánková \& Gežík 2014, Stanciu \& Ionita 2014, Molnár et al. 2016). Several changes took place which influenced the protected area administrations as well. In this period, nature conservation was struggling with complex problems. On the political level, despite the fact that the CEE counties ratified most of the international agreements (even in the Communist period), protected areas were lacking the political will and support (Drgona \& Turnock 2001, Ioras 2003, Bojnec \& Latruffe 2013). At the economic level, the pressure on protected areas was represented by agricultural encroachment, commercial overharvesting of natural resources, and chaotic infrastructure development (Zellei et al. 2005, Kohlheb \& Krausmann 2009, Bezák \& Halada 2010). At the social level, nature conservation was facing insufficient outreach and partnerships, lack of community support and lack of enforcement (Stringer \& Paavola 2013).

\section{Challenges of the present - governance of protected areas in the European context}

\section{Integration of EU policy by public institutions}

EU accession included a set of new regulations and institutional changes for the new member states. A detailed overview on the challenges in public administration faced by the countries visited in this study is available in Liebert et al. (2013). Shortly, the EU Environmental acquis has to be harmonized with the remnants of the totalitarian communist systems.

The most significant challenge was, and still is, the establishment of the Natura 2000 network (Hochkirch et al. 2013). Fulfilling the requirements of the Habitats and Birds Directives quickly overshadowed the ongoing conservation initiatives for national ecological networks (Mikulcak et al. 2013, Sarvašová et al. 2013, Balázs et al. 2016). Harmonizing the management plans of Natura 2000 sites with the plans of other existing protected areas is the most difficult step, especially for Romania and Slovakia (Iojă et al. 2010, Křenová \& Kindlmann 2015, Hossu et al. 2017). The Natura 2000 network was more successfully implemented in the Czech Republic, and Hungary. Hence, the new Czech Biodiversity Strategy (2016-2025) rather focuses on setting pragmatic priorities for nature conservation in developing societies, than on the network itself. Surprisingly, other countries are still giving a significant attention to Natura 2000 network de- 
velopment and management, even after more than 10 years of designation.

However, with EU accession several meaningful possibilities become available for the CEE countries like international a professional network of specialist in nature conservation, transboundary management and EU funds for conservation (Křenová \& Kindlmann 2015). Nature conservation initiatives have started to occupy a niche and become an important discussion partner and decision maker for development plans and projects. For example, some directorates of the national parks in Hun- gary (e.g. Hortobágy) have become landowners of significant amounts of the protected areas or are responsible for administrating the state property (Stanciu \& Ionita 2014). In the White Carpathians important areas were purchased by nature conservation authorities and restored to species-rich hay meadows - being transformed in arable land during collectivization (Jongepierová et al. 2007).

A general comparison is presented in Table 1 on how different countries approach protected area governance and management.

Table 1: Comparison on the most important features in protected areas with direct influence on the grassland habitats' management and conservation (based on participant observation).

Tabela 1: Primerjava najpomembnejših lastnosti zavarovanih območij z neposrednim vplivom na gospodarjenje $s$ traviščnimi habitati in njihovim varovanjem (na osnovi opažanj deležnikov).

\section{Analyzed aspects Czech Republic}

governance and management of protected areas
Delegated to state nature conservation at regional level and national park administrations; NGOs have an important participative role.
Slovakia

Delegated to state nature Centralized; covered and conservation authority; some NGOs have meaningful contribution in conservation initiatives.
Hungary coordinated by the national parks directorates, based on their operational area; NGOs have limited participation, because of the centralized system.
Romania

Delegated to administrators - large scale protected areas (10 year contract) or custodians - small scale protected areas (5 year contract); $\mathrm{NGO}$ participation is remarkable.

Medium overall situation, debatable quality in some of the cases (fist plans); integrated management plans for Natura 2000 and national protected area categories; compulsory conservation measures; buffer zones are within the limits of the national parks. tional parks.

\section{Restitution of property} rights to former landowners; viable small-scale farms, producing mostly for self-consumption; after EU accession considerable changes in farming structure; small-scale farms are not eligible for rural development programs.

Survival of traditional farming practices and small-scale farms; to maintain connection of people with their land. 


\section{Gap between policy and practice}

The gap between policy and practice in grassland conservation and management is created by: (i) the very different objectives of the directives, coming from the conflicting paradigms of nature conservation and agriculture; (ii) the inflexibility of institutions to mediate between policy makers and practitioners (e.g. farmers, conservationists); (iii) agriculture becoming a profit oriented activity of companies (registered farmers), and no longer a way of living of families, which were functionally part of the biodiversity rich farming landscapes.

The effectiveness of EU policies in halting biodiversity loss is questionable, especially in landscapes with a history of intensive farming management (Kleijn et al. 2011, Plieninger et al. 2012, Sutcliffe et al. 2013, Arlettaz et al. 2014). The agri-environmental schemes require major improvement in the CEE countries (e.g. to develop results-oriented schemes, specified requirement for different zones, simplified accession) and real harmonization with nature conservation objectives (Sutcliffe et al. 2015). Compensatory payments for conservation measures are available only in isolated cases, being part of the agri-environmental schemes. Despite the invested efforts (e.g. institutional, monetary, political), grasslands habitats have one of the highest proportion of 'unfavourable - bad' or 'deteriorating' status. Effective conservation of these ecosystems depends on the extensive farming, which is functional part of a 'healthy' social-ecological system (Bignal \& McCracken 2000, Halada et al. 2011, Plieninger \& Bieling 2013).

In addition, weak collaboration exists between the institutions responsible for nature conservation and agriculture authorities in these countries (Apostolopoulou \& Pantis 2009, Křenová \& Kindlmann 2015, Lieskovský et al. 2015, Hossu et al. 2017). This creates difficulties to implement regulations in-situ, especially for the reward systems. The lack of knowledge transfer on the subject of grassland management and protected area governance enlarges the gap between the science, practice and public administration (Cogăniceanu \& Cogălniceanu 2010, Cent et al. 2013, Mihók et al. 2015, Orlikowska et al. 2016).

Unfortunately, the socio-economic changes of the last century have led to the abolition of extensive farming systems in the Czech Republic, Slovakia and Hungary (Drgona \& Turnock 2001, Bogaerts et al. 2002). Disconnection of people from their land was much more highlighted there, than it was in Romania. Romania has an advantage: many of the land users still maintain the natural functions of the species-rich grasslands based on local traditional knowledge (Babai \& Molnár 2013,Florentina et al. 2015, Loos et al. 2015). This situation is much more a result of local circumstances (subsistance or semi-subsistance conditions), not conservation oriented approach (Hartel et al. 2014), which makes the traditional systems highly vulnerable to the new trends in globalization.

Maintaining land-use and land management practices within the cultural landscape is not a conscious choice of the farmers. Human-nature interactions created an informal framework of unwritten conservation rules, which have been respected for centuries with minimal intervention from institutions (Hartel et al. 2014). The knowledge from such informal structures must be integrated within formal institutional systems and policy and conservation strategies at a local level. As long as the land owners and users have a participatory role in the nature conservation actions, public institutions can profit from the viability of these social-ecological systems (e.g. biocultural refugia, sensu Barthel et al. 2013).

Therefore, a holistic approach is needed in the case of grasslands, in order to re-establish functional social-ecological systems in all of the countries and resilience based perspectives need to be integrated (Plieninger \& Bieling 2013).

\section{Lessons learned in protected areas of the Czech Republic, Slovakia and Hungary}

What follows is a summary of the most important observations made in the protected areas visited during this study.

\section{Box 1. The White Carpathians Landscape Protected Area - Czech Republic}

- The Czech part of the White Carpathians is administrated by regional nature conservation authorities, covering $715 \mathrm{~km}^{2}$, overlapping different categories of protected areas. The WCLPA is well known for its large species-rich hay meadows.

- Significant NGO support strengthens the meadows' conservation. Several projects were implemented in collaboration with conservation authorities to restore meadows from arable land, using regional seed mixtures. Monitoring plots and experimental fields were established for more than 20 years to develop practice-based conservation.

- Instead of focusing on local conservation of habitats/ species, grassland ecosystems are considered functional part of the landscape in conservation strategies.

- Mosaic mowing represented a fruitful compromise for mechanization and nature conservation. However, abandonment and plant succession still represents a 
risk for species-rich hay meadows. An applicable solution was land acquisition of protected sites and accession of funds for conservation measures from different sources (e.g. Life, national grants).

- Agri-environmental schemes integrated some of the conservation initiatives (e.g. use of regional seed mix- tures for over seeding), but it is impossible to cover measures for particular species or habitats. Farmers perceive the conservation oriented grassland management as unusual, complicated despite of higher compensation.

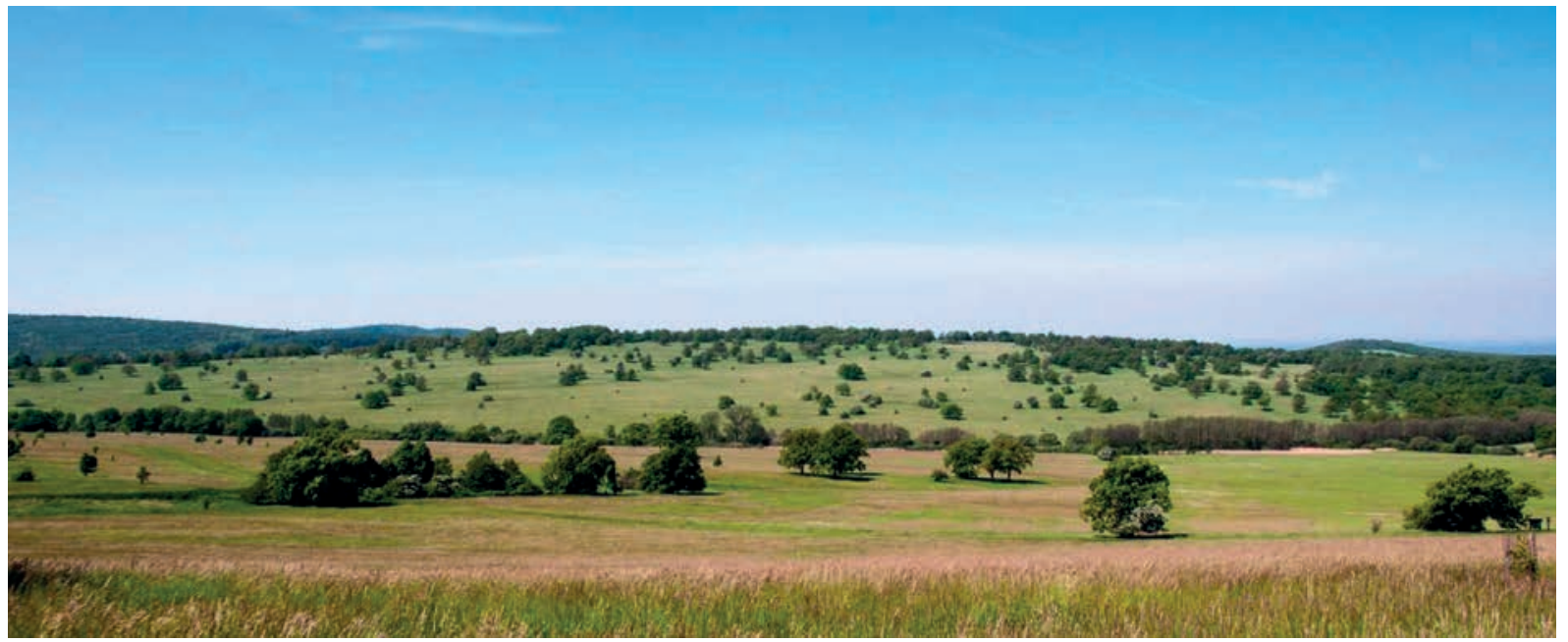

Figure 1: Traditional cultural landscape in Certoryje with species-rich hay meadows and scattered trees; this area is famous about the meadows' species-richness and it is the most well preserved area of the White Carpathians Protected Landscape Area.

Slika 1: Tradicionalna kulturna krajina na območju Certoryje z vrstno bogatimi gojenimi travniki in redko posajenimi posameznimi drevesi; območje je poznano po vrstno bogatih travnikih in je najbolj ohranjeno območje v Zavarovanem krajinskem območju Beli Karpati.

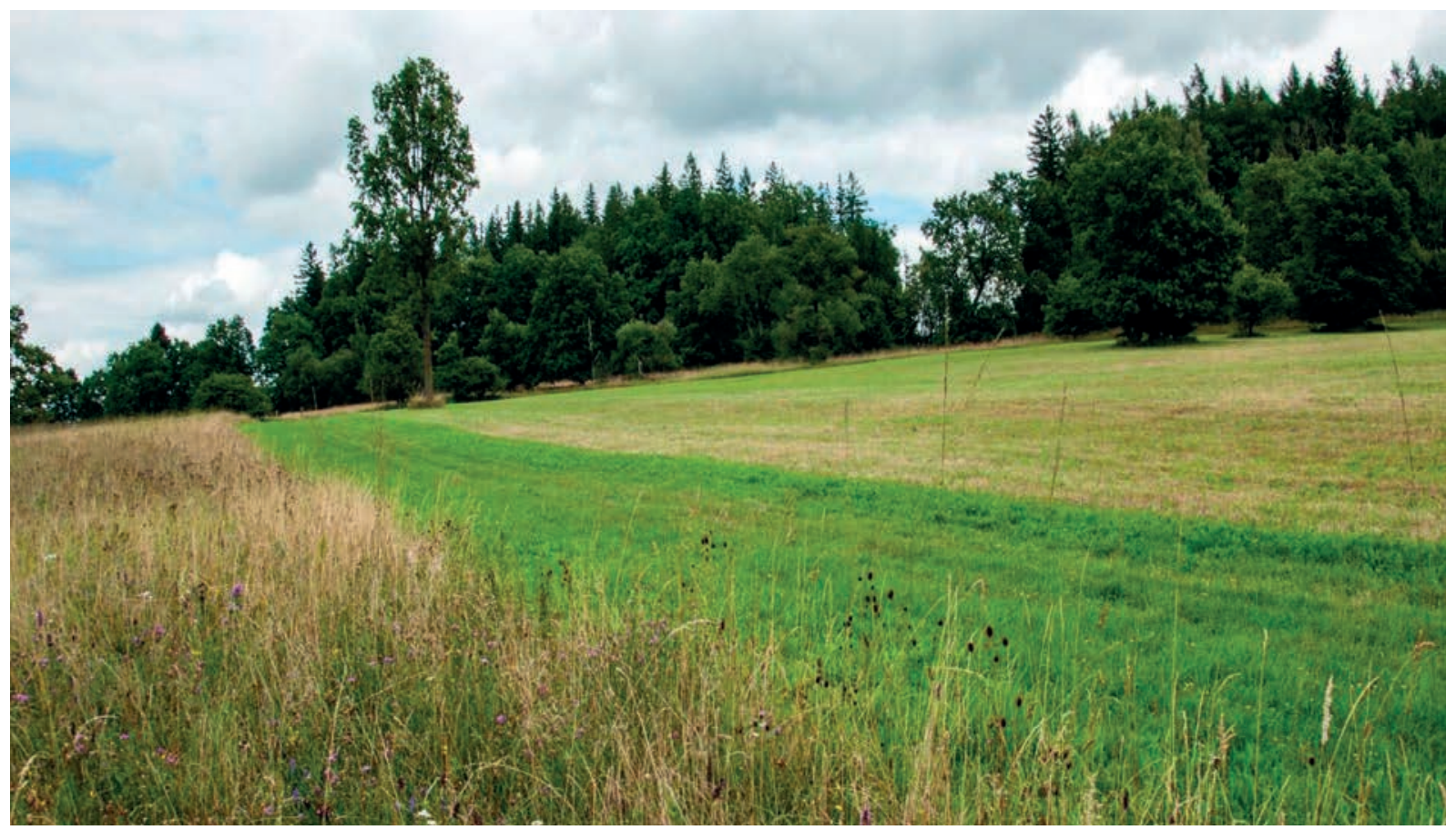

Figure 2: Different stages of the vegetation applying mosaic mowing in the White Carpathians.

Slika 2: Različne stopnje vegetacije pri mozaičnem načinu košnje v Belih Karpatih. 


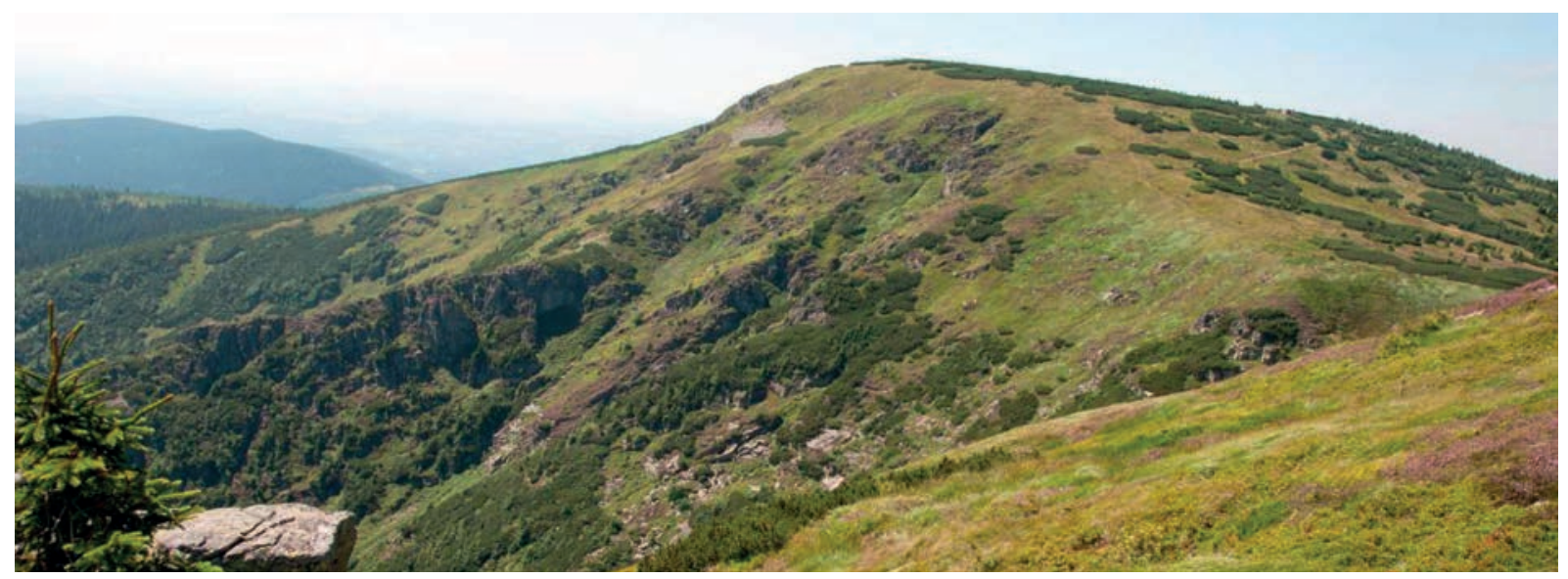

Figure 3: Traditional agricultural activities were abandoned after World War II; no active grassland management (use) was re-established. Slika 3: Tradicionalno gospodarjenje so po drugi svetovni vojni opustili in aktivnega gospodarjenja s travišči niso več vzpostavili.

\section{Box 2. The Krkonoše Mountains National Park - Czech Republic}

- The Czech part belongs to the Administration of KMNP and covers $425 \mathrm{~km}^{2}$ ha, overlapping more categories of protected areas. This is one of the most visited national parks in the world for its touristic infrastructure (e.g. cross-country ski, ski resorts, mountain bike trails, hiking trails).

- The local towns in the proximity (buffer zone) are the most important recreation centers. The new management plan (2010-2020) proposed changes in the initial zonation, which generated a series of debates, but was successfully approved.

- Several research and educational projects have been performed in order to achieve favourable conservation of the grassland habitats and raise awareness within local community about their importance.

- The migration of German communities after World War II from the mountain area caused the abolition of traditional farming systems and changes in the landscape structure.

- Managed hay meadows represent just small amount of the grassland habitats and because of their low economic interest they are threatened by abandonment. The conservation measures need often negotiation or compromises with farmers especially in case of private properties. Several grassland areas are property of the park, but without active farming they are vulnerable for succession. (Figure 4)

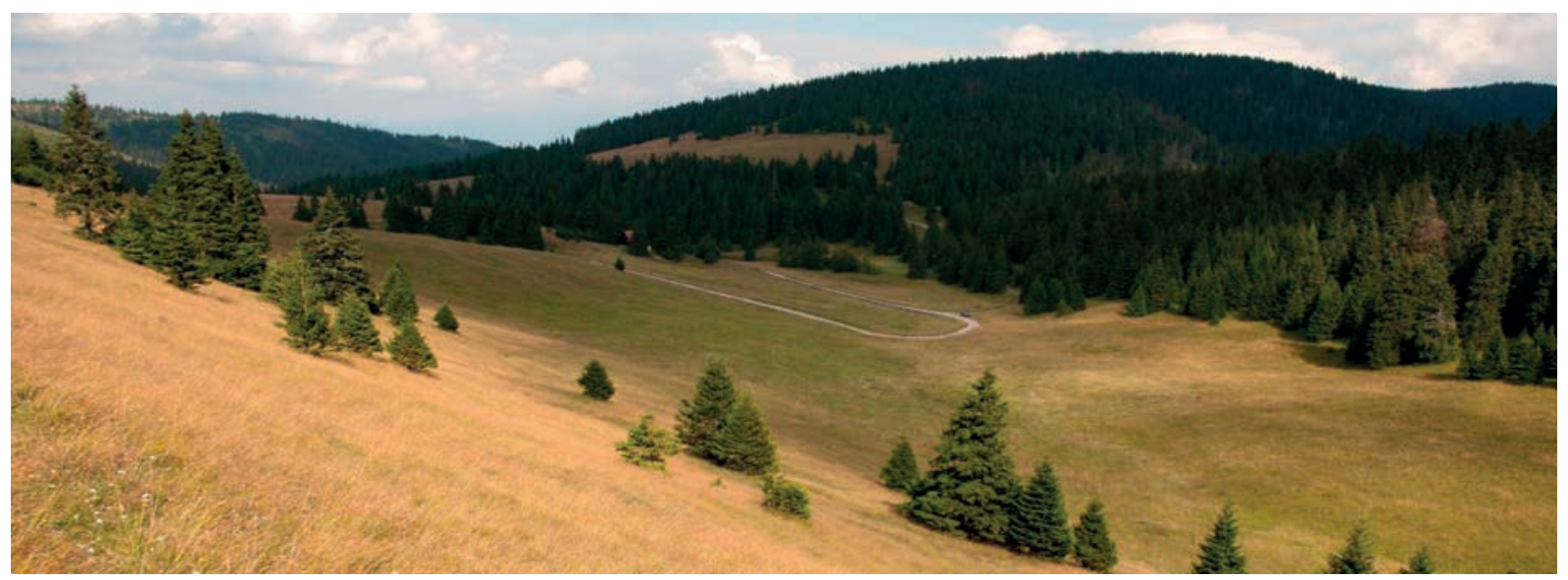

Figure 4: Animal husbandry was mostly abandoned at higher elevations; in some areas grazing is restricted (e.g. stop erosional processes, vegetation protection). Other areas, like on the picture, are not regularly mowed or grazed. Old cooperative farms were restructured in the valleys and are functioning mostly for milk, cheese production (Great Fatra National Park).

Slika 4: Živinorejo so opustili na višjih nadmorskih višinah; na nekaterih območjih je paša prepovedana (zaradi preprečitve erozijskih procesov, ohranjanja vegetacije). Druga območja, kot to na sliki, pa neredno kosijo ali pasejo. Stare zadružniške kmetije so v dolinah obnovili in proizvajajo predvsem mleko in sir (Narodni park Velika Fatra). 


\section{Box 3. The Low Tatra National Park and the Great Fatra National Park - Slovakia}

- The national parks are administrated by the Slovak Nature Conservancy covering $728 \mathrm{~km}^{2}$ (LTNP) and $261 \mathrm{~km}^{2}$ (GFNP) overlapping more categories of protected areas. In the last 10 years several restructuration took place which downgraded the national park administrations capacity (e.g. economically and number of employees).

- The administrations have no property rights in the area, nor administrate any state property. The complex ownership structure makes difficult to regulate human activities within the parks (e.g. farming, forestry, tourism, investments).

- Abandonment, followed by fast succession, threatens the semi-natural grasslands in upper areas. The productive grasslands are managed by cooperatives of local farmers, which were reestablished after the communist era. They have no interest, however, to manage the hardly accessible grasslands, especially hay meadows. The cooperatives slowly eliminated small plots and property borders, causing changes in the landscape structure.

- The agri-environmental schemes are generally established for the whole county and cannot cover sufficient conservation requirements on regional or local scales. It is difficult, to access any compensation for special conservation measures as long as the harmonization of management plans (Natura 2000 sites overlapped with national park) still taking place. The most important areas under conservation (mostly in natural reserves) are managed by the employees of the park administrations. National park administrations, or nature conservancy are not directly involved in the elaboration of agri-environmental schemes. (Figure 5)

\section{Box 4. The Hortobágy National Park - Hungary}

- The national park directorates in Hungary fulfill administrative functions on larger areas than their administrative territory and other categories of protected area. The HNP covers about $820 \mathrm{~km}^{2}$ and overlaps with a multitude of protected area categories.

- The HNP has an advantage, because the HNP Directorate owns huge amount of land, or administrates state property within the park. Their administrative role is more difficult in Natura 2000 sites due to the variety of property rights.

- However, the directorate has just consultative role in decision making for environmental regulation processes, which belongs to the Environment and Nature Protection Inspectorates.

- More governmental support (e.g. institutional, economic, political) would grant better administrative capacity of the directorate.

- Actual challenges in grassland habitat management and conservation relates to grazing and mowing strategy:

- a) regulation of pasturing (who? when? where? and which kind of animals?): to guaranty optimal SLU/ha for different weather conditions (e.g. rainy, dry) and site conditions; to make pasturing rules compulsory

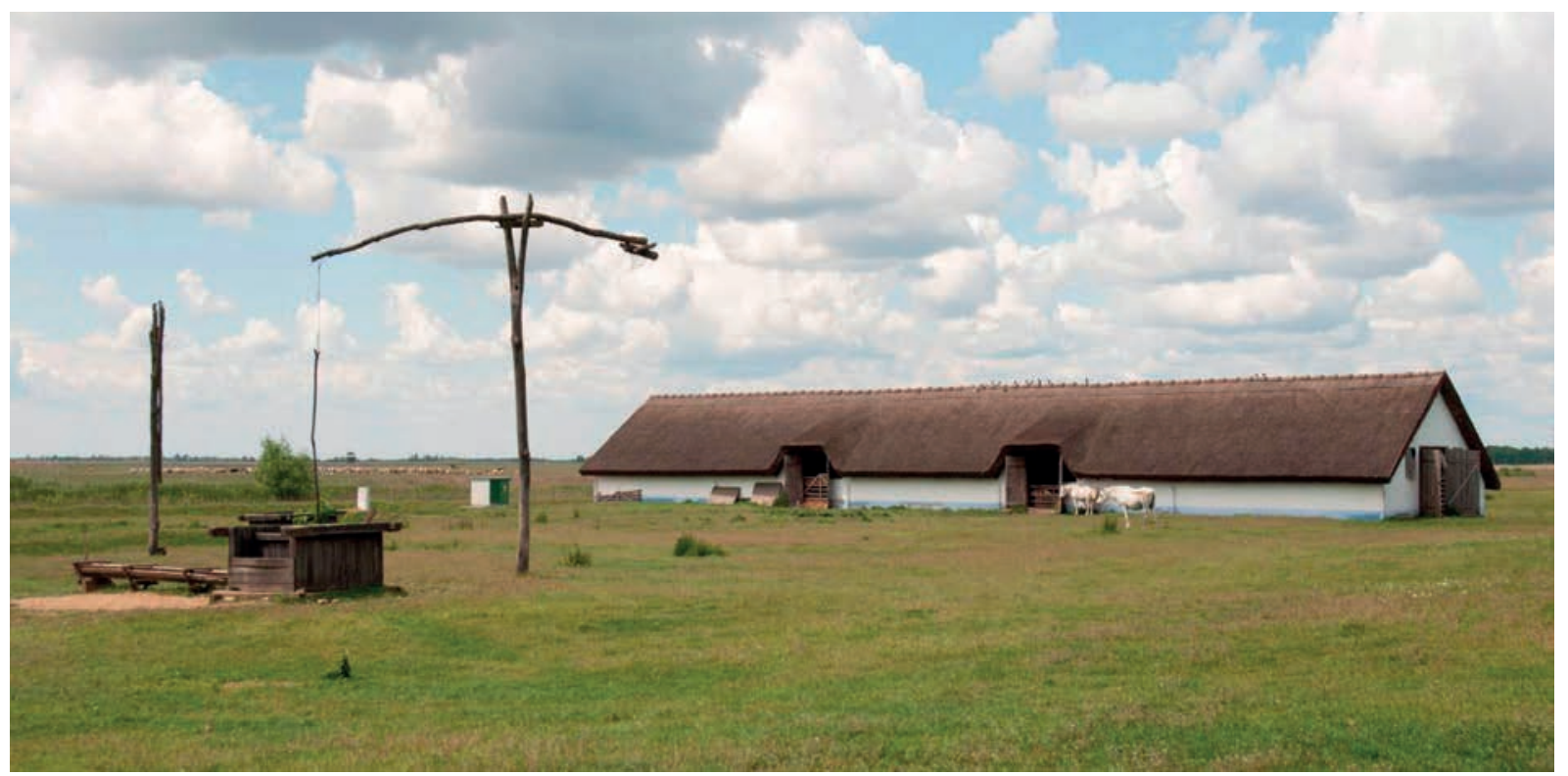

Figure 5: Traditional farm in the Hortobágy National Park.

Slika 5: Tradicionalna kmetija v Narodnem parku Hortobágy. 


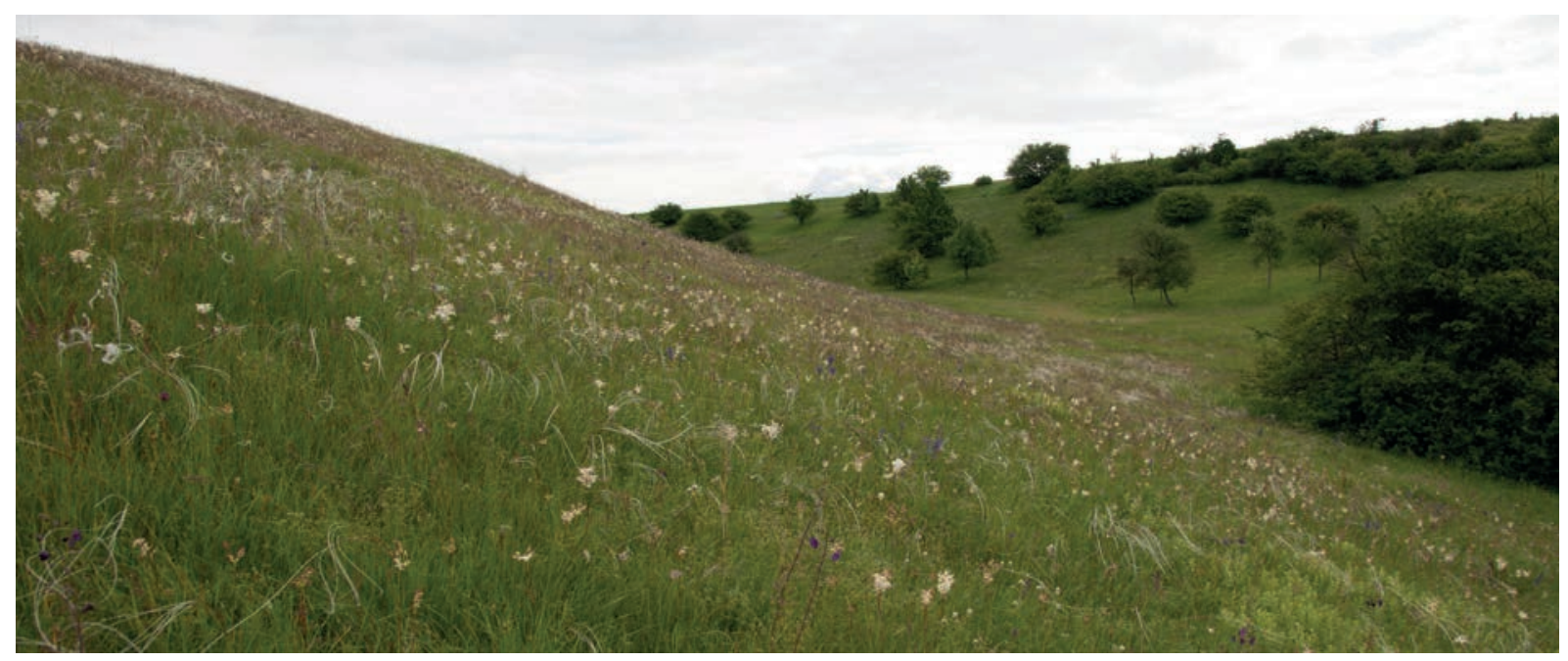

Figure 6: Dry grasslands in May (Bükk National Park).

Slika 6: Suha travišča v maju (Narodni park Bükk).

for the farmers; to maintain traditional land use practices and landscape structure (e.g. common grazing with grey cattle, racka sheep and wild horses);

- b) regulation of moving (when? where? and how?): to simplify the electronic registration and monitoring system for mowing period approval; to maintain mosaic moving for conservation; to adapt mowing for certain species conditions (isolated cases);

- Landscape restoration projects have been implemented to eliminate canals, dikes and replacing wire lines with underground cable, restoring wetlands, establishment of best grazing practices for conservation; collaboration with the scientific area could be better developed in the future. Considerable effort is now being given to combat the invasive plant species and re-establish the natural herbaceous vegetation.

\section{Box 5. The Bükk National Park - Hungary}

- The BNP Directorate has minimal property right, but plays an administrative role over the limits of the national park. The state property, mostly forests $(94 \%)$, is administrated by state forest corporations. Grassland habitats are unimportant from forester's perspective, being under the regulation of forest management plans. The most species-rich grasslands are under strict protection. The national park covers about $420 \mathrm{~km}^{2}$ overlapping with different categories of protected areas.

- Natura 2000 sites management guidelines should focus better on the regulation of permitted activities instead of enumeration of prohibited actions.

- The BNP Directorate has just a consultative role in the decision making.
- The directorate faces difficulties in the management of grasslands (unfavorable conservation status in EU classification) especially in Natura 2000 habitats. Mowing and grazing were abandoned between 19601970. To re-establish animal husbandry, hay making and pasturing, in actual unfavorable economic conditions is mostly impossible (e.g. variety of property rights, conflicting objectives with forestry and unfavorable subsidies for extensive farming).

- Experimental projects are under development, testing the best pasturing practices on the Dél-Heves area, connected to bird species conservation as well.

- Several landscape restoration projects and combating invasive woody species were implemented. Unfortunately, land abandonment prevents restoration on long term.

\section{Conclusions}

The political, social, economic and environmental context of the last century has generated complex and synergistic challenges for the effective nature conservation in the CEE countries. The top-down governance model and centralized administrative power has resulted in people's disconnection from their land over almost two generations. Therefore, the manner of designation of protected area networks in the communist era created from the beginning (i) a gap between local communities and authorities and (ii) a formal protection of sites lacking financial support for management, personnel capacity and technical equipment. These gaps have not been bridged in all of the cases. 
The main challenges for the post-communist countries lies in their capacity to: (i) access complementary funds for nature conservation, beside their inadequate annual budget for nature conservation, assured by the governments; (ii) harmonize the policy implementation between nature conservation and agriculture; (iii) bridge the gaps between science, practice and policy by continuous knowledge transfer between research, farmers, conservationist and employee of public institutions, politicians; and (iv) address regional, often local problems, raised around the implementation.

Organizational changes in the structure of ministries at a central and regional level are necessary in order to balance the disparities between their responsibilities. The gaps between public administration, managers of protected areas and stakeholders must be bridged within integrated multilevel governance (e.g. nature conservation and agriculture) instead of a domain oriented approach (e.g. nature conservation or agriculture). The knowledge transfers from research to public administration and between institutions could be a huge advantage making the public administration respond more realistically and flexible to the needs of social-ecological systems. Sustainable agricultural practices must be developed and adopted to local conditions in order to respond to the conservation objectives.

Furthermore, detailed comparative case studies can lead to a deeper understanding of the complexity of the current situation for countries in transition, focusing on the history of political systems, changes in property rights and land use after Communism.

\section{Acknowledgements}

This study was founded by the Alfred Toepfer Natural Heritage Scholarship, offered by the Alfred Toepfer Foundation and Europarc Federation in 2016. I would like to express my gratitude for the persons who provided a great support in organizing my field visits. I am very thankful for Michał Żmihorski and Jonathan Mitchley improving the early version of this manuscripts with their useful and constructive comments. The manuscript was inspired by the framework of the STACCATO project (BiodivERsAFACCE2014-47) where I am currently involved.

\section{References}

Apostolopoulou, E. \& Pantis, J. D. 2009: Conceptual gaps in the national strategy for the implementation of the European Natura 2000 conservation policy in Greece. Biological Conservation 142(1): 221-237. https://doi.org/10.1016/j.biocon.2008.10.021

Babai, D., \& Molnár, Z. 2013: Multidimensionality and scale in a landscape ethnoecological partitioning of a mountainous landscape (Gyimes, Eastern Carpathians, Romania). Journal of Ethnobiology and Ethnomedicine 9: 11. https://doi.org/10.1186/1746-4269-9-11

Balázs, B., Pataki, G. \& Lazányi, O. 2016: Prospects for the future: Community supported agriculture in. Futures 83: 100-111. https:// doi.org/10.1016/j.futures.2016.03.005

Barthel, S., Crumley, C. \& Svedin, U. 2013: Bio-cultural refugiaSafeguarding diversity of practices for food security and biodiversity. Global Environmental Change 23(5): 1142-1152. https://doi. org/10.1016/j.gloenvcha.2013.05.001

Batáry, P., Dicks, L. V., Kleijn, D. \& Sutherland, W. J. 2015: The role of agri-environment schemes in conservation and environmental management. Conservation Biology 29(4): 1006-1016.

Bezák, P. \& Halada, L. 2010: Sustainable Management Recommendations to Reduce the Loss of Agricultural Biodiversity in the Mountain Regions of NE Slovakia. Mountain Research and Development 30(3): 192-204. https://doi.org/10.1659/MRDJOURNAL-D-10-00023.1

Bezák, P. \& Mitchley, J. 2014: Drivers of change in mountain farming in Slovakia: from socialist collectivization to the Common Agricultural Policy. Regional Environmental Change 14(4): 1343-1356.

Bičík, I., Jeleček, L., \& Štěpánek, V. 2001: Land-use changes and their social driving forces in Czechia in the 19th and 20th centuries. Land Use Policy 18(1): 65-73.

Bignal, E. M. \& McCracken, D. I. 2000: The nature conservation value of European traditional farming systems. Environmental Reviews, 8(3): 149-171. https://doi.org/10.1139/er-8-3-149

Blicharska, M., Orlikowska, E. H., Roberge, J. M. \& GrodzinskaJurczak, M. 2016: Contribution of social science to large scale biodiversity conservation: A review of research about the Natura 2000 network. Biological Conservation 199: 110-122. https://doi. org/10.1016/j.biocon.2016.05.007

Bogaerts, T., Williamson, I. P. \& Fendel, E. M. 2002: The role of land administration in the accession of Central European countries to the European Union. Land Use Policy 19(1): 29-46.

Bojnec, Š. \& Latruffe, L. 2013: Farm size, agricultural subsidies and farm performance in Slovenia. Land Use Policy 32: 207-217. https:// doi.org/10.1016/j.landusepol.2012.09.016

Burger, A. 2006: Why is the issue of land ownership still of major concern in East Central European (ECE) transitional countries and particularly in Hungary? Land Use Policy 23(4): 571-579. https://doi. org/10.1016/j.landusepol.2005.01.003

Cent, J., Mertens, C. \& Niedziałkowski, K. 2013: Roles and impacts of non-governmental organizations in Natura 2000 implementation in Hungary and Poland. Environmental Conservation 40(02): 119-128. https://doi.org/10.1017/S0376892912000380

Cogălniceanu, D. \& Cogălniceanu, G. C. 2010: An enlarged European Union challenges priority settings in conservation. Biodiversity and Conservation 19(5): 1471-1483. https://doi.org/10.1007/s10531010-9777-1 
Drgona, V. \& Turnock, D. 2000: Policies for rural Eastern Europe in transition: The case of Slovakia. Geo Journal 50(2-3): 235-247.

European Comission 2015: Report from the Commission to the European Parliament and the council. The mid-term review of the EU Biodiversity Strategy to 2020. http://eur-lex.europa.eu/legal-content/ $\mathrm{EN} / \mathrm{TXT} / \mathrm{PDF} /$ ?uri=CELEX:52015DC0478\&from=EN

Fischer, J., Hartel, T. \& Kuemmerle, T. 2012: Conservation policy in traditional farming landscapes. Conservation Letters 5(3): 167-175. https://doi.org/10.1111/j.1755-263X.2012.00227.x

Florentina, G. I., Maria, C. S., Adrian, L. \& Simona, M. 2015: Better Governance for Biodiversity Conservation is Possible in Romania? Journal of Environmental Science and Engineering Technology 3: 210. https://doi.org/10.12974/2311-8741.2015.03.01.1

Gorlach, K., Los, M. \& Mooney, P. H. 2008: Agriculture, communities, and new social movements: East European ruralities in the process of restructuring. Journal of Rural Studies 24(2): 161-171. https://doi.org/10.1016/j.jrurstud.2007.12.003

Halada, L., Evans, D., Romão, C. \& Petersen, J. E. 2011: Which habitats of European importance depend on agricultural practices? Biodiversity and Conservation 20(11): 2365-2378. https://doi. org/10.1007/s10531-011-9989-z

Hartel, T., Fischer, J., Câmpeanu, C., Milcu, A. I., Hanspach, J. \& Fazey, I. 2014: The importance of ecosystem services for rural inhabitants in a changing cultural landscape in Romania. Ecology and Society 19(2). https://doi.org/10.5751/ES-06333-190242

Henle, K., Alard, D., Clitherow, J., Cobb, P., Firbank, L., Kull, T., ... Young, J. 2008: Identifying and managing the conflicts between agriculture and biodiversity conservation in Europe - A review. Agriculture, Ecosystems and Environment 124(1-2): 60-71. https:// doi.org/10.1016/j.agee.2007.09.005

Hochkirch, A., Schmitt, T., Beninde, J., Hiery, M., Kinitz, T., Kirschey, J., ... Proelss, A. 2013: Europe Needs a New Vision for a Natura 2020 Network. Conservation Letters 6(6): 462-467. https:// doi.org/10.1111/conl.12006

Hossu, C. A., Ioja, I. C., Nita, M. R., Hartel, T., Badiu, D. L. \& Hersperger, A. M. 2017: Need for a cross-sector approach in protected area management. Land Use Policy 69: 586-597.

Iojă, C. I., Pătroescu, M., Rozylowicz, L., Popescu, V. D., Vergheleț, M., Zotta, M. I. \& Felciuc, M. 2010: The efficacy of Romania's protected areas network in conserving biodiversity. Biological Conservation 143(11): 2468-2476. https://doi.org/10.1016/j. biocon.2010.06.013

Ioras, F. 2003: Trends in Romanian biodiversity conservation policy. Biodiversity and Conservation 12(1): 9-23. https://doi. org/10.1023/A:1021254615841

Isselstein, J., Jeangros, B. \& Pavlů, V. 2005: Agronomic aspects of biodiversity targeted management of temperate grasslands in Europe A review. Agronomy Research 3(2): 139-151.

Jongepierová, I., Mitchley, J. \& Tzanopoulos, J. 2007: A field experiment to recreate species rich hay meadows using regional seed mixtures. Biological Conservation 139(3-4): 297-305. https://doi. org/10.1016/j.biocon.2007.07.026

Kati, V., Hovardas, T., Dieterich, M., Ibisch, P. L., Mihók, B. \& Selva, N. 2014: The challenge of implementing the European network of protected areas Natura 2000. Conservation Biology 29(1): 260-270. https://doi.org/10.1111/cobi.12366
Kleijn, D., Rundlöf, M., Scheper, J., Smith, H. G. \& Tscharntke, T. 2011: Does conservation on farmland contribute to halting the biodiversity decline? Trends in Ecology and Evolution 26(9): 474-481. https://doi.org/10.1016/j.tree.2011.05.009

Kluvánková, T. \& Gežík, V. 2014: Survival of commons? Institutions for robust forest social-ecological systems. Journal of Forest Economics 24: 175-185. https://doi.org/10.1016/j.jfe.2016.01.002

Knorn, J., Kuemmerle, T., Radeloff, V. C., Szabo, A., Mindrescu, M., Keeton, W. S., ... Hostert, P. 2012: Forest restitution and protected area effectiveness in post-socialist Romania. Biological Conservation 146(1): 204-212. https://doi.org/10.1016/j.biocon.2011.12.020

Kohlheb, N. \& Krausmann, F. 2009: Land use change, biomass production and HANPP: the case of Hungary 1961-2005. Ecological Economics, 69(2): 292-300. https://doi.org/10.1016/j. ecolecon.2009.07.010

Křenová, Z. \& Kindlmann, P. 2015: Natura 2000-Solution for Eastern Europe or just a good start? The Šmava National Park as a test case. Biological Conservation 186: 268-275. https://doi.org/10.1016/j. biocon.2015.03.028

Lemaire, G., Wilkins, R. \& Hodgson, J. 2005: Challenges for grassland science: Managing research priorities. Agriculture, Ecosystems and Environment 108(2): 99-108. https://doi. org/10.1016/j.agee.2005.01.003

Levers, C., Butsic, V., Verburg, P. H., Müller, D. \& Kuemmerle, T. 2016: Drivers of changes in agricultural intensity in Europe. Land Use Policy 58: 380-393. https://doi.org/10.1016/j.landusepol.2016.08.013

Liebert, S., Condrey, S. E. \& Goncharov, D. 2013: Public administration in post-communist countries: Former Soviet Union, central and Eastern Europe, and Mongolia. CRC Press.

Lieskovský, J., Bezák, P., Špulerová, J., Lieskovský, T., Koleda, P., Dobrovodská, M., ... \& Gimmi, U. 2015: The abandonment of traditional agricultural landscape in Slovakia-Analysis of extent and driving forces. Journal of Rural Studies 37: 75-84. https://doi. org/10.1016/j.jrurstud.2014.12.007

Loos, J., Turtureanu, P. D., Wehrden, H. Von, Hanspach, J., Dorresteijn, I., Frink, J. P. \& Fischer, J. 2015: Plant diversity in a changing agricultural landscape mosaic in Southern Transylvania (Romania). Agriculture, Ecosystems \& Environment 199:, 350-357. https://doi.org/10.1016/j.agee.2014.10.013

Mihók, B., Kovács, E., Balázs, B., Pataki, G., Ambrus, A., Bartha, D., ... Báldi, A. 2015: Bridging the research-practice gap: Conservation research priorities in a Central and Eastern European country. Journal for Nature Conservation https://doi.org/10.1016/j.jnc.2015.09.010

Mikulcak, F., Haider, J. L., Abson, D. J., Newig, J. \& Fischer, J. 2015: Land Use Policy Applying a capitals approach to understand rural development traps: A case study from post-socialist Romania. Land Use Policy 43: 248-258. https://doi.org/10.1016/j. landusepol.2014.10.024

Mikulcak, F., Newig, J., Milcu, A. I., Hartel, T. \& Fischer, J. 2013: Integrating Rural Development and Biodiversity Conservation in Central Romania. Environmental Conservation 40(2): 129-137. https://doi.org/10.1017/S0376892912000392

Molnár, Z., Kis, J., Vadász, C., Papp, L., Sándor, I., Béres, S., ... \& Varga, A. 2016: Common and conflicting objectives and practices of herders and conservation managers: the need for a conservation herder. Ecosystem Health and Sustainability 2(4). https://doi.org/10.1002/ ehs 2.1215 
Orlikowska, E. H., Roberge, J. M., Blicharska, M. \& Mikusiński, G. 2016: Gaps in ecological research on the world's largest internationally coordinated network of protected areas: A review of Natura 2000. Biological Conservation 200:216-227. https://doi.org/10.1016/j. biocon.2016.06.015

Oszlányi, J., Grodzińska, K., Badea, O. \& Shparyk, Y. 2004: Nature conservation in Central and Eastern Europe with a special emphasis on the Carpathian Mountains. Environmental Pollution 130(1):

127-134. https://doi.org/10.1016/j.envpol.2003.10.028

Pe'er, G., Dicks, L. V., Visconti, P., Arlettaz, R., Báldi, A., Benton, T. G., Collins, S., Dieterich, M., Gregory, R. D., ... Scott, A V. 2014: EU agricultural reform fails on biodiversity. Science 344(6188): 1090-1092. https://doi.org/10.1126/science.1253425

Plieninger, T. \& Bieling, C. 2013: Resilience-based perspectives to guiding high nature value farmland through socio-economic change. Ecology and Society 18(4). https://doi.org/10.5751/ES-05877-180420

Plieninger, T., Schleyer, C., Schaich, H., Ohnesorge, B., Gerdes, H., Hernández-Morcillo, M. \& Bieling, C. 2012: Mainstreaming ecosystem services through reformed European agricultural policies. Conservation Letters 5(4): 281-288. https://doi.org/10.1111/j.1755263X.2012.00240.x

Sarvašová, Z., Šálka, J. \& Dobšinská, Z. 2013: Mechanism of cross-sectoral coordination between nature protection and forestry in the Natura 2000 formulation process in Slovakia. Journal of Environmental Management 127: 65-72. https://doi.org/10.1016/j. jenvman.2012.06.005

Stanciu, E. \& Ioniță, A. 2014: Governance of protected areas in Eastern Europe. Overview on different governance types, case-studies and lessons. Bfn-Skripten, 360.

Stoate, C., Báldi, A., Beja, P., Boatman, N. D., Herzon, I., van Doorn, A., ... Ramwell, C. 2009:. Ecological impacts of early 21 st century agricultural change in Europe - A review. Journal of Environmental Management 91(1): 22-46. https://doi.org/10.1016/j. jenvman.2009.07.005

Stringer, L.C. \& Paavola, J. 2013: Participation in environmental conservation and protected area management in Romania: A review of three case studies. Environmental Conservation 40(2): 138-146. doi: $10.1017 /$ S0376892913000039

Sutcliffe, L. M. E., Batáry, P., Kormann, U., Báldi, A., Dicks, L. V., Herzon, I., ... Tscharntke, T. 2015: Harnessing the biodiversity value of Central and Eastern European farmland. Diversity and Distributions 21(6): 722-730. https://doi.org/10.1111/ddi.12288

Sutcliffe, L., Akeroyd, J., Page, N. \& Popa, R. 2015: Combining approaches to support high nature value farmland in southern Transylvania, Romania. Hacquetia, 14(1), 53-63. https://doi. org/10.1515/hacq-2015-0011

Sutcliffe, L., Paulini, I., Jones, G., Marggraf, R. \& Page, N. 2013: Pastoral commons use in Romania and the role of the Common Agricultural Policy. International Journal of the Commons 7(1): 58-72.

Švajda, J. \& Fenichel, E. P. 2011: Evaluation of integrated protected area management in Slovakian National Parks. Polish Journal of Environmental Studies 20(4): 1053-1060.

Van Dijk, T. 2007: Complications for traditional land consolidation in Central Europe. Geoforum 38(3): 505-511. https://doi.org/10.1016/j. geoforum.2006.11.010

Varga, A., Molnár, Z., Biró, M., Demeter, L., Gellény, K., Miókovics, E., ... \& Babai, D. 2016: Changing year-round habitat use of extensively grazing cattle, sheep and pigs in East-Central Europe between 1940 and 2014: Consequences for conservation and policy. Agriculture, Ecosystems \& Environment 234: 142-153.

Zellei, A., Gorton, M. \& Lowe, P. 2005: Agri-environmental policy systems in transition and preparation for EU membership. Land Use Policy 22(3): 225-234. https://doi.org/10.1016/j.

landusepol.2003.09.008

\section{Documents and websites used for desk study}

EU Biodiversity Strategy 2020 http://ec.europa.eulenvironment/nature/info/pubs/docs/ brochures/2020\%20Biod\%20brochure\%20final\%20lowres.pdf

Hungarian Biodiversity Strategy 2015-2020 http://www.termeszetvedelem.hu/_user/browser/File/Stragegial MK15083_NBS.pdf

Czech Biodiversity Strategy 2016-2025 https://www.cbd.int/doc/world/cz/cz-nbsap-v2-en.pdf

Slovak Biodiversity Strategy 2020 https://www.cbd.int/doc/world/sk/sk-nbsap-v3-en.pdf

Romanian Biodiversity Strategy 2014-2020 https://www.cbd.int/doc/world/ro/ro-nbsap-v3-ro.pdf

Carpathian Integrated Biodiversity Information System http://www.ccibis.org/carpathian-values/100-nature-protection-andprotected-area-legislation

Czech Nature Conservation and Landscape Protection http://www.cittadella.cz/europarclindex.php? $p=$ historie_ ochranyersite $=$ zakladni_udaje_en

Family Farming in Romania http:/lec.europa.eu/agriculture/sites/agriculture/files/consultations/ family-farming/contributions/adept_en.pdf

Hungarian Nature Conservation Authority http://www.termeszetvedelem. hu/index.php?pg=menu_1729

Hungarian Nature Conservation Information System http://geo.kvvm.hultir_en/

Protected areas of Romania http://www.propark.ro/images/uploads/file/manual\%20arii\%20 protejate_net.pdf

Hortobágy National Park Directorate Webpage: http://www.hnp.hu

Bükk National Park Directorate Webpage: www.bnpi.hu

National Park Nízke Tatry (Low Tatras) Webpage: http://www.napant.sk/

National Park Velka Fatra Webpage: http://www.sopsr.sk/velkafatraweblen

Krkonoše Mountains National Park: www.krnap.cz

White Carpathians Protected Landscape Area Webpage: http://vis.bilekarpaty.cz 